\title{
The Convergence of Crowd Funding and Zakat System in India: An Integrated Approach for Human Welfare
}

\author{
Muhammad Ashiq ${ }^{1}$, Ubaid Mushtaq ${ }^{2}$ \\ ${ }_{1 *, 2}$ Department of Humanities and Social Sciences \\ Indian Institute of Technology, Kharagpur, India \\ * muhammedashiqv55@gmail.com
}

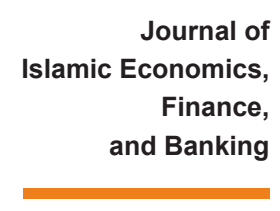

Vol. 3, No. 1, Juni 2020 , pp. 27-36, ISSN p:2622-4755 e:2622-4798

\section{Abstract}

Introduction: The impact of the Zakat system on human welfare is well established. In India, there is a significant development in terms of localised management of zakat system. However, the targeted delivery of zakat funds, unorganised collections and lack of transparency remain a matter of concern. There is no formal institutional mechanism for efficient Zakat distribution, and problems of circularity are at mostly affecting the progress of welfare mechanisms. Problems of circularity of Zakat funds are still, largely, incoherent and practically disconnected with the mechanics of philanthropic institutions.

Purpose/Objective Study: This paper aims to develop a conceptual model for integrating zakat funds with crowdfunding platform in India.

Design/Methodology/Approach: we attempt to conceptualize the problem in zakat funds circularity. Subsequently, we attempt to put up the conceptual model of crowdfunding and integrate with zakat delivery mechanism. Lastly, we provide the relevance of this particular model in the context of India and conclude with the implications of the proposed model.

Findings: The findings of this research we expect to bring transparency in zakat fund circulation in the country through the integration of zakat funds with internet-enabled crowdfunding. In order to bring transparency, there is a need to reform the zakat institutions. It supposed to reduce the socio-economic backwardness of Muslims through the use of zakat funds for productive purposes.

Paper Type: Research Article

Keywords: Banks Zakat welfare; Circularity; Crowdfunding; India

\section{Introduction}

In Islam institution of zakat is an integral part of the overall socioeconomic wellbeing of the community. With the inception of zakat, Muslims have had an obligation to donate a particular amount of their wealth to needy under some specific conditions. It is one of the five
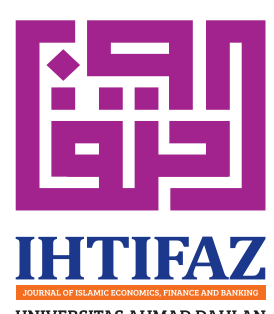

UNIVERSITAS AHMAD DAHLAN

Kampus 4

Universitas Ahmad Dahlan Jl. Ringroad Selatan, Tamanan anguntapan, Bantul Yogyakarta 55191 
pillars of Islam as well as the nature of beneficiaries are also well stated. The primary aim of zakat is to increase human welfare and to achieve IHTIFAZ - JIEFB socio-economics justices. The socio-economic dimension of zakat is also well established and have favourable effects on various dimensions such as consumption, eradication of poverty and economic growth for those who lack economic support and or poor. However, in the context of zakat institution's efficiency and governance, there are still some critical issues which need immediate attention. Many problems afflict the structure of zakat institution towards achieving socio-economic justices. It can be in the form of improper distribution of funds, targetable delivery of social welfare mechanism and other mechanisms that creates hurdles for the development opportunities for the needy and are desirable Muslims. There is still an informality in Zakat distribution, and problems of circularity are affecting the progress for welfare of poor Muslims. While on the one hand in the circularity are still abundant on the other

Zakat funds are still, largely, incoherent and practically disconnected with the mechanics of philanthropic institutions. Usually, in relatively prosperous chunks of Muslim communities, Zakat circulation happens only within that localized community due to lack of any efficient management of zakat welfare delivery system. On the other side, needy people living in different regions are not getting appropriate benefits due to these structural problems of the circuitry of zakat funds. Thus an aspect of novelty in this paper is an attempt to prepare a theoretical model for integrating crowdfunding with zakat institution. The study will contribute to the dearth of empirical and conceptual studies on zakat delivery system and will widely address the problems faced by Ummah.

The remaining part of this paper is structured as follows. Second section deals with the background of the study and review of the specific scholarly articles related to zakat funds and problems being faced in zakat delivery system. After that, we attempt to conceptualize the problem in zakat funds circularity. Subsequently, we attempt to put up the conceptual model of crowdfunding and integrate with zakat delivery mechanism. Lastly, we provide the relevance of this particular model in the context of India and conclude with the implications of the proposed model.

\section{Literature Review}

Zakat is considered as one of the five fundamental pillars mentioned in Islam. The payment of zakat is said to be an act of worship and social investment (Saad\& Haniffa,2014). As a moral and ethical responsibility, Zakat is compulsory for every Muslim to donate $2.5 \%$ of his annual savings for the social wellbeing. However, unorganized form of zakat collection, lack of transparency among the individuals and institutions which receive the zakat funds and unprofessionalism in the management of zakat fund together are causing a colossal economic loss. 
In the context of India, Muslims are the largest minority community with 14.4 per cent (Census of India,2011) of India's total population. However, the socio-economic and cultural status of the Muslims varies across the states and union territories in India. For instance, the living conditions of Muslims in Kerala is much better than the Muslims in Utter Pradesh and West Bengal. As a result of this, in relatively more prosperous chunks of Muslim communities, Zakat circulation is within that specific area only considering the convenience in the localised management of zakat welfare delivery system. On the other side, the real and needy people living in different regions are not getting appropriate benefits due to these structural problems of the circuitry of zakat funds. The local management of zakat leads to the prosperity of the prosperous region. At the same time, it continues the poor living conditions in the other end. To improve the living conditions of the Muslims across India, we need to have a professionally organize zakat system from collection to distribution of zakat funds.

The $68^{\text {th }}$ round of National Sample Survey Office (NSSO) estimate (2011-12) suggest that the average per capita consumption expenditure of Muslims is 32.66 rupees. It considered the lowest among all the religions in India. Consumption expenditure often considered as a proxy of poverty estimation. Further, job market indicators like labour force participation rate, employment status and worker population ratio are low among the Muslims as compared with other communities. For example, NSSO data indicates that LFPR among Muslims is 342 and 337 per 1000 population in urban and rural area, respectively. It means that only 342 Muslims are employed in the urban area out of 1000 working-age Muslims. All these symptoms may lead the community to the vicious circle of poverty unless there is no effort to improve the poor with the help of community itself under the existing Hindutva forces in the Government and administrative level. These statistics shows that Muslim community does not benefit from the Government of India (GOI) policies such as Integrated Rural Development Programme (IRDP, 1980), Sampoorna Gramin Rozgar Yojana (SGRY,2001), Mahatma Gandhi National Rural Employment Guarantee Act (MGNREGA, 2005), National Rural Livelihood Mission (NRLM,2011) to reduce unemployment and poverty. The statistics says that $25 \%$ of India's beggars belong to the Muslim community. It is generally believed the India bring 170 million people out of poverty after 1990. Surprisingly, new studies suggest there is no much change in poverty since 1950; bottom people are still at the bottom of the strata(Asher.et al, 2018). It further necessitates the need for the community development within the community itself, so that we need to have the proper mechanism of zakat management system beyond local management.

Studies related to the educational accessibility of the Muslims in India are concern as there is a substantial decline in all aspects of 
education in comparison to the historically marginalized; Scheduled castes (SCs) and scheduled tribes (STs). India's Muslim community has

for long faced discrimination in every place and relatively lower living standards. Previous studies highlight that the Muslim community has the lowest rate of enrollment in higher education in India, accounting for just $4.4 \%$ of students. If we develop an integrated approach for Zakat management, then we can use the Zakat funds for productive purpose like the educational improvement of the community. The Rajinder Sachar Committee Report(SCR,2006) and other studies related to the marginality identified that there are three crucial dimensions of social exclusion, i.e. backwardness, marginalization and discriminations for Muslims in India.

In the present political scenario of India is totally against the survival of the Muslims. According to the Crime Records Bureau, hate crimes against Muslims shoot up during the first five years (2014-2019) tenure of Narendra Modi (Present PM of India). On this back drop, we are motivated to develop a well-managed zakat fund for the improvement of Indian Muslims.

\section{Developmental impacts of Zakat funds}

The study of Suhaib (2009) evaluates the emergence of zakat system and impact on social development. It found that every individual will be able to get the basic needs of life. Further, it helps to reduce the concentration of wealth in the hands of the few by redistribution in Pakistan. In an analysis based on Indonesia by Hafidhuddin and Beik (2019) found that there is an existence of a gulf between zakat potential and its actual collection. The study suggests some solution mechanism, that should be formal, professional and transparent. zakat management is a crucial instrument that can elevate the dignity and prosperity of the Muslims not only in Indonesia but also in other Muslim countries.

In a Pakistan based study of Azam et al. (2014) empirically investigated using the regression analysis to explore the role of social welfare through Zakat. The result indicates that zakat enhances economic development in the country both in the household level and the country level. The study advice for the institutionalization of a formal collection system for zakat to increase the overall collection of zakat funds.

In a study of Shirazi (1994) in Pakistan explores the impact of Zakat and ushr on poverty alleviation. The study highlights that Zakat alleviated poverty in Pakistan at about 2.0 per cent in the year 1987-88. Similarly, in a study of Nurzaman (2010) aim to understand the impact of productive-based Zakat effectiveness in improving the welfare of Zakat recipient at Jakartha in Indonesia. The take study not only take income for the analysis, but it also takes education and health. For the purpose, the study created a Human Development Index ( HDI ) for the Zakat 
recipient. The result indicates that the HDI value of Zakat recipients are below the current average HDI of Jakarta and Indonesia. In addition to this, this study found that resources are allocated for production purpose than consumption benefit more to the recipient of Zakat.

\section{Problems of circularity}

Malik (2016) argues that due to the problem of wealth accumulation in onside generate bifurcation in the state in the form of two classed namely "privileged class" and "deprived class". The economic prosperity of "privileged class" over "deprived class" has become one of the significant hurdles in the way of achieving welfare and social justice in any system. In this situation, it is being argued that "re-institutionalization" of zakat, is the means to provide socio-economic insurance to those who are otherwise neglected. By offering the "constructive channelization" of wealth from "privileged class" to "deprived class" institution of zakat can overcome the problems like relative deprivation, poverty, illiteracy, unemployment.

Ali (1998) in his paper, suggested that zakat should be formalised and institutionalized and he also goes on to argue that if there are no Muslim states, then it should be institutionally operative by people. He further argues that the practice of zakat should do the calculation and payment of zakat through sharia and government and community institutions established collectively established by general people should collect and distribute zakat for the better circulation. A study of Lessy (2009) based on Indonesia raised the issue related to circularity and credibility in the past. Lessy found that institutions of zakat are not transparent to the general public and doesn't account for money collected and distributed.

This lack of accountability made the public largely lose their interest in giving zakat; they were sure about who received their donations, but not who received it later. Zeb and Zaman (2014) explore Zakat as a sort of social safety net in Pakistan as it addresses the problems faced by Zakat Recipients in the collection of Zakat assistance from the committee responsible for local distribution. For analysing the same, they have conducted a survey of 80 respondents in Latif Abad in Peshawar. The study found that Zakat is not ineffectively to improve the socio-economic conditions of the Zakat recipient since they are facing lot of problem in receiving the assistance.

\section{Conceptualizing problems of circularity}

It is essential to have an understanding about who should be the recipient of Zakat fund. For this, it is necessary to bring a priority-based list of really needy Muslims for Zakat funds, if we don't have any proper understanding about the needy people then the circulation of zakat funds 
is a matter of concern. In addition to this, from the donor point of view unless the zakat donor does not know the what amount of Zakat to be paid, then it will lead to the deficiency of Zakat funds and ultimately creating a way to create problems of circuitry.

As a result of these problems, the circulation of zakat funds requires immediate attention. Furthermore, the Muslim does not have sufficient information about the items that comes under zakat. There are three views related to the items on which zakat is due. In the traditional approach, it is seen as the majority view on what zakat should be duly imposed. Zakat based on the traditional view is levied on agriculture, livestock, stock in trade, gold, silver, and money.

Another view is based on contemporary Muslims scholars and includes all of the items in the traditional view and also wealth that is deducted from net returns of manufacturing or building rents and substantial savings. The third and final approach consists of no movable and fixed assets, except those assigned for personal and family use. So all these three approaches can be used to build up an efficient circularity mechanism of zakat funds.

\section{Conceptual Model}

\section{Introduction to crowdfunding}

Crowdfunding is a collective effort of a large pool of individuals to raise funds through various platforms. It helps to reduce the complexities associated with other forms of funding in terms of the reach to target.

There are various types of crowdfunding, as far as the Zakat fundraising is concerned, it is necessary to follow donation-based crowdfunding since there is no financial incentive for the donor as such. Undoubtedly, the reward from Allah is above all. In this backdrop, we propose a donation-based crowdfunding for the management of zakat at the national level. It has the following benefits: Reach -there is much opportunity to get Zakat funds for the poor people; trust- the donors of zakat funds have an opportunity to clarify the doubts related with zakat fund transfer and its utilization; efficiency-if the crowdfunding is through the online it will help to reduce the manual preparation of documents related to zakat.

In the context of India, online donation-based crowdfunding is a possible way, since there is a continuous increase in internet usage (See Figure.1). Hence it helps to reach the target people along with rising fund and monitoring the performance with a more credible way. 
Figure 1. Individuals Using the Internet

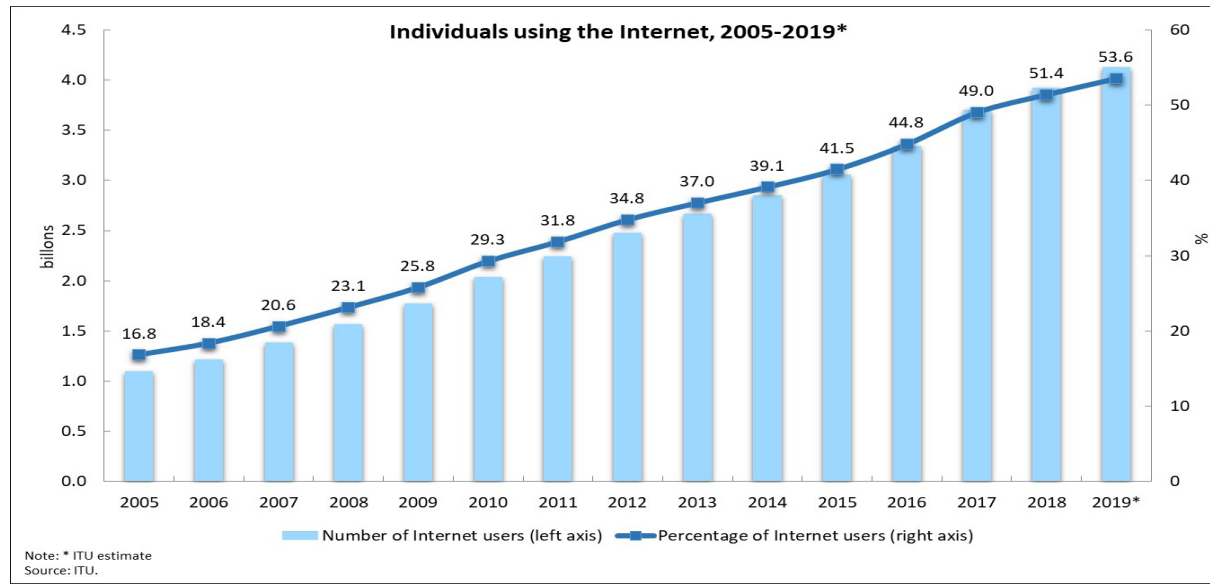

According to Internet and Mobile Association of India (IAMAI), India is in the second rank in internet usage after china with 451 million internet users at the end of 2019. It indicates that there is a scope for introducing an internet-enabled donation-based crowdfunding for the improvement of standard of living of the Muslim community in India. Crowdfunding also enable people to lobby support not just from and within the country but also across the world. For this purpose, we can utilise social media as a means to achieve this goal; it helps to reach people beyond our network.

\section{Integrating local Zakat funds with a Pan Nation based crowdfunding}

There is a need to integrate crowdfunding structure with zakat distribution, and it can be achieved through a multi-stage framework. This integration involves identification of welfare programmes or projects for Muslim communities through locally established and duly recognised Waqaf boards. This need could also be raised and integrated through Auqaf committees in specific areas, where Waqaf boards have no direct access. After disseminating this information through waqf boards and synchronised it state waqf boards will take a call and prioritise projects based on nature and its immediate need. Correspondingly, such need-based projects will be taken on one digital platform and invite collaborations from general zakat donors. Collection of funds will be raised centrally and then allocated to projects. Eventually, project updates and evaluation of projects will also be done and updated on the one centralised platform.
Journal of

Islamic Economics,

Finance,

and Banking

Vol. 3, No. 1, Juni 2020 , pp. 27-36, ISSN p:2622-4755 e:2622-4798 
Figure 2. Integrating local Zakat funds with a Pan Nation based crowdfunding

\section{IHTIFAZ - JIEFB}

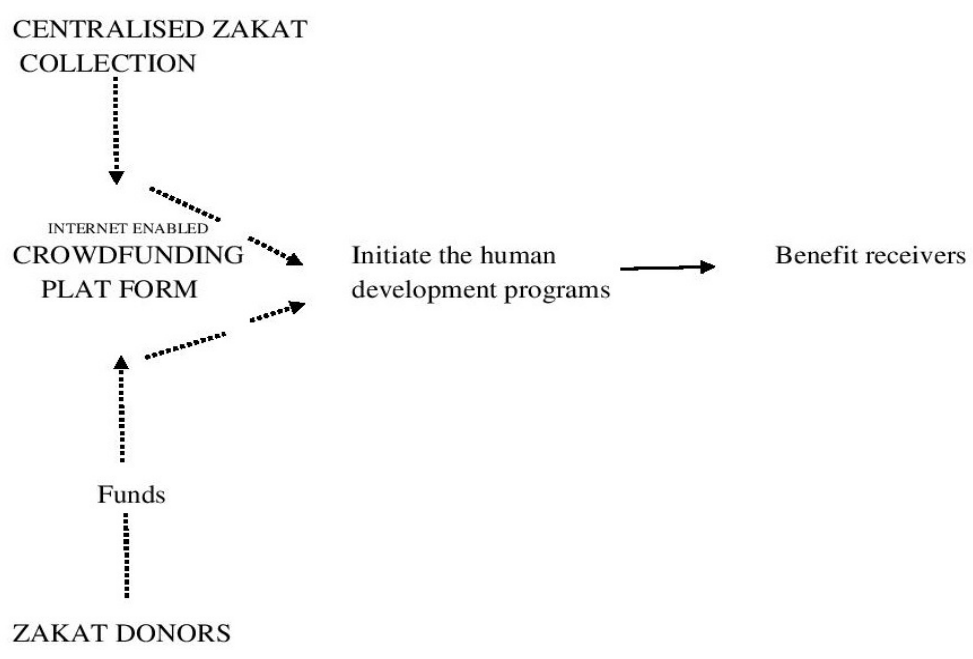

\section{Potential Impact on Welfare Mechanism}

Zakat helps the community to fulfil its basic needs and enable them to develop the capabilities. The integration of zakat with crowdfunding will mainly help in building efficient zakat mechanism. Based on the Shari'a zakat is provided for eight classes alone; the indigent, the poor, the person being tamed at his heart, freed slaves, people who owe, fighting in Allah's way, and travellers. If these class of people in the community benefitted adequately through this centralised zakat management system, hence the major part of the community can develop like other communities in all the sphere of life in India.

Unlike earlier zakat form, i.e. consumption-oriented zakat, the new integrated system allows focusing on the development and empowerment programs. Integrating both empowerment and development programs will have a positive effect on those who are in dire need and also has the potential to create opportunities to improve socio-economic conditions. It will later also create an environment of self-help and change in social structure regardless of any dependency on socio-political structures.

The critical property of the zakat funds in the newly developed system is that utilization of these funds for those activities which generate income for the deprived sections within the community. This could help in setting upscale units and other empowerment programs for poor section in Muslim communities. There is also a potential of improving their welfare and reduce the overall poverty rate.

In a nutshell, this development will help the community to achieve higher life expectancy, literacy rate and consumption expenditure. Thereby increase the human development index of the overall community. 


\section{Relevance to a broader Zakat fund integration}

Under the New International Economic Order(NIEO), it is necessary to reform the institutions and processes to adjust with changing context not only in India but all over the world. It is highly essential in the case of Indian Muslims due to the emergence of Hindutva forces all over the country. The emergence of Hindutva is a treat to the socio-politicaleconomic existence of the Muslims.

The present government try to implement the Hindutva by the nationalist agenda. In this backdrop, it is essential to develop a system which fulfils the basic needs such as food, drinking water, sanitation, health, and education among Muslims. It is found that till now in India, there is no proper mechanism of Zakat through crowdfunding to attain the wellbeing of the Muslims.

Crowdfunding provides platforms that are transparent and with progress updates on campaigns - features which are needed to improve the traditional zakat distribution or localised zakat management system. Further, an internet-based crowdfunding platform can able to collect and distribute appropriately.

\section{Conclusion}

This paper aims to develop a conceptual model for integrating zakat funds with crowdfunding platform in India. The emergence of Hindutva forces is challenging the socio-economic and political existence of the Muslims. It tries to use fuel to fire policy by adopting various types of islamophobia related activities not only at the national levels but also at the regional level. It is identified that there is a need to help the economically weak Muslims to improve their living standards with the help of relatively wealthy Muslims in India. For that, we need to collect the zakat funds properly with trust and transparency. From this conceptual model, we expect to bring transparency in zakat fund circulation in the country through the integration of zakat funds with internet-enabled crowdfunding. In order to bring transparency, there is a need to reform the zakat institutions. It supposed to reduce the socio-economic backwardness of Muslims through the use of zakat funds for productive purposes.In future researchers can use this conceptual model for the empirical validation by using the statistical and econometrics tools.

\section{References}

Ali, M.D. (1998). Sistem ekonomi Islam zakat dan wakaf. (The system of Islamic economy of zakat and waqf). Jakarta: University of Indonesia Press.

Al Jaffri Saad, R., \& Haniffa, R. (2014). Determinants of zakah (Islamic tax) compliance behavior. Journal of Islamic Accounting and Business Research, 5(2), 182-193.

Ihtifaz: Journal of Islamic Economics, Finance, and Banking 
Asher, S., Novosad, P., \& Rafkin, C. (2018). Intergenerational Mobility in India: Estimates from New Methodsand Administrative Data. World IHTIFAZ - JIEFB Bank Working Paper. Available at: http://www. dartmouth. edu/ novosad/anr-india-mobility. pdf (accessed December 2018)

Azam, M., Iqbal, N., \& Tayyab, M. (2014). Zakat and economic development: Micro and macro level evidence from Pakistan. Bulletin of Business and Economics, 3(2), 85-95.

GOI (2011). Census of India 2011.Registrar General and Census Commissioner of India, Ministry of Home Affairs, New Delhi, India

GOI (2011-2012). National Sample Survey Office - NSSO- 68 th round, Ministry of Statistics \& Programme Implementation, New Delhi, India

Hafidhuddin, D., \& Beik, I. S. (2019). Zakat Development: The Indonesia's Experience. Al-Infaq: Jurnal Ekonomi Islam, 1(1).

IAMAI. (n.d.). from https://www.iamai.in/

Lessy, Z. (2009). Zakat (alms-giving) management in Indonesia: Whose job should it be?. La_Riba, 3(1), 106-119.

Malik, B. A. (2016). Philanthropy in Practice: Role of Zakat in the Realization of Justice and Economic Growth. International Journal of Zakat, 1(1), 64-77.

Secretariat, C. (2006). Social, Economic and Educational Status of the Muslim Community of India. Development Economics Working Papers

Shirazi, N. S. (1994). An Analysis of Pakistan's Poverty Problem and Its Alleviation through Infaq. PhD Dissertation. International Islamic University, Islamabad.

Suhaib, A. Q. (2009). Contribution of Zakat in the Social Development of Pakistan. Pakistan Journal of Social Sciences (PJSS), 29(2).

Zeb, A., \& Zaman, G. (2014). Assessing the Role of Zakat as a Social Safety Net and problems faced by Zakat Recipients in receiving Zakat Assistance in Pakistan. Abasyn University Journal of Social Sciences, $7(1)$.
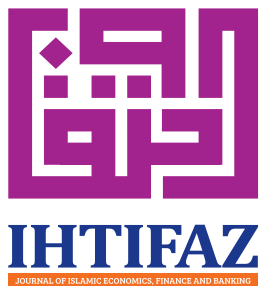

UNIVERSITAS AHMAD DAHLAN

Kampus 4 Universitas Ahmad Dahla Jl. Ringroad Selatan, Tamanan Banguntapan, Bantul e-mail : intifaz@uad.ac.id 